\title{
Effect of Penicillium frequentans and Stachybotrys chartarum on respiratory metabolism of developing eggs of Ascaris suum (Nematoda)
}

\section{LIDIA KOEODZIEJCZYK ${ }^{1}$, WANDA KUZNA-GRYGIEL ${ }^{1}$, KRYSTYNA JANOWICZ ${ }^{2}$, and KINGA MAZURKIEWICZ-ZAPALOWICZ ${ }^{3}$}

${ }^{1}$ Chair of Biology and Medical Parasitology, Pomeranian Academy of Medicine in Szczecin

Al. Powstartoów Wielkopolskich. 72, PL-70-111 Szezecin, Poland, c-mail: Ikolo@scipam.szczecin.pl

${ }^{2}$ Chaiz of Applied Entomology, Agricultural Academy of Szezecin, Stowackiego 17, PL-71-434 Szczecin, Poland

"Chair of Zoology, Agricultural Academy of Szczocin, Judyma 20, PL-71-466 Szezecin, Poland

Kołodzicjczyk L., Kuźna-Grygiel W, Janowicz K, Mazurkiewicz-Zapałowicz K.: Effect of Penicilium frequentans and Stachybotrys chartanum on respiratory metabolism of developing eggs of Ascaris sutum (Nematada). Acta Mycol. 36 (1): 159-168, 2001.

Effect of saprotrophic soil fungi Penicilliwm frequentans and Stachybotrys chartarum on espiratory metabolism of Ascaris suum, during its embryogenesis was determined using histoenzymatic methods. Based on histochemical assessmeat of the cnzyme activity (glycolysis-lactate dehydrogenase-LDH; tricarboxylic acid cycle-succinate dehydrogenase-SDH), changes in the energy metabolism of developing eggs of $\boldsymbol{A}$. sutm were detected. Of the fungi species tested $-\boldsymbol{P}$. frequentans caused the most extensive disorders in the processes of cellular oxidation, which were manifested in a decline of SDH activity during gastrulation. Incubation of eggs of Ascaris with mycelia of both fungi: $S$. chartarum and $P$. frequentans - in lesser extend affected respiratory metabolism in embryogenesis of this nematode.

Kcy words: soil fungi, oxidative enzymes, Ascaris sutum.

\section{INTRODUCTION}

Biotic factors along with abiotic ones play a significant role in controlling numbers and dispersal of eggs of Ascaris and other geobelminths in soil (Mizgajsk a 1993). The major groups of soil organisms limiting the quantities of parasite eggs in soil are: fungi, mites, springtails, and bacteria (Lysek 1967, 1986; Mizgajska 1994). Variable-intensity ovistatic and ovicidal 
effects on Ascaris eggs were observed in relation to different saprotrophic soil fungi (L y s e k 1963, 1967, 1979; L y s e k et al. 1986; K u n e r t 1992).

Antagonistic properties of $\boldsymbol{P}$. frequentans were demonstrated in rclation to Pytiom - a pathogen of sprouts of a beet and charlock ( $\mathrm{L} \mathrm{i} \mathrm{u}$ and $\mathrm{V}$ a $\mathrm{u} \mathrm{g}$ h a n 1965). It was also demonstrated that numerous strains of this specics inhibited development of Streptomyces griseus (cf. $\mathrm{M} \mathrm{i} \mathrm{r} \mathrm{c} \mathrm{h} \mathrm{i} \mathrm{u} \mathrm{k}$ and B e l a y a 1965) and bacteria Erwinia carotovora (cf. K h a r che n k o 1960) and Staphylococcus aureus (cf. O r a z o v and S iz o v a 1966). Also, fungistatic and fungicidic properties of this species were stated in relation to Beauveria bossiana and $B$. brongniartii (cf. Kal'vish 1972) and $F$. sporotrichoides (cf. S i z o v a and V a s in 1962). Good confirmations of biological activity of strains of $P$. frequentans are their strong cellulolytic (D o m s c h 1960; K a n e v s a y a 1966) and proteolytic propertics.

$S$. chartarum is onc of common saprotrophs occurring in upper layers of soil It can also be present in animal-husbandry buildings. Its inhibiting properties were observed in relation to rape, tomato, and linen (D o m s c h 1963). It also demonstrates strong cellulolytic properties (D o m s c h 1960; T r ibe 1960; K a n e v s k a y 1966). Many strains of this species have pectinolytic (Cochrane 1958), chitinolytic (D o m s c h 1960), and fungistatic properties (D h in g r a and $\mathrm{K} \mathrm{h}$ a re 1973; D o m s c h and $\mathrm{G} \mathrm{a} \mathrm{m} \mathrm{s} \mathrm{1968;}$ $\mathrm{G}$ h a f f a r and F a t im a 1970; $R$ a i and S a x c a 1975).

Ovistatic properties of mycelia of $S$. chartarum and $P$. frequentans in relation to development of $A$. suum eggs were demonstrated in our other paper (K u ż n a - G r y g i c 1 et al. 2001). They were manifested in retardation of sequential stages of the embryogenesis and occurrence of developmental defects. $P$. frequentans exhibited decisively strongest antagonistic effect among the mould fungi studied.

The aim of the present work was the assessment of the effect of both fungi species (separately and in conjunction) on oxidative metabolism during embryonic development of Ascaris suum.

\section{MATERIAL AND METHODS}

The specimens of Ascaris sutm were collected from pigs at the Municipal Slaughterhouse in Szczecin. Fertilised parasite eggs, used in the present study, were dissected from the terminal portion of uteri of nematode females. The eggs were placed in petri dishes in $0.9 \% \mathrm{NaCl}$ solution (control culture) and in the same $\mathrm{NaCl}$ concentration with mycelium fragments of: Penicillium frequentans (experimental culture No. 1), Stachybotrys chartarum (experimental culture No. 2), and both fungi (experimental culture No. 3).

Saprotrophic mould fungi - Penicillium frequentans and Stachybotrys chartarum isolated from soil, were cultured on a standard substrate (PDADifco medium) in petri dishes at $25^{\circ} \mathrm{C}$. Mycelium-substrate circular pieces ( $40 \mathrm{~mm}$ in diameter) were cut out from 21 -day cultures of each species and they 
were placed in petri dishes along with eggs of Ascaris suam in $\mathrm{NaCl}$ solution (experimental cultures Nos. 1 and 2). Similarly procedure was applied to the two-species arrangement of mould fungi (culture No. 3). Subsequently the petri dishes were incubated in an incubator at $26^{\circ} \mathrm{C}$ for 41 days.

In the course of the experiment, eggs from experimental cultures and control culture were monitored daily under a microscope. Based on the observation in control culture, the following developmental stages were defined: 0-day-old eggs, immediately after dissection from the nematode uterus, zygotc, carly stages of cleavage $\left(2,4, n\right.$-blastomeres), morula, gastrula, $L_{1}$ larva, $\mathrm{L}_{2}$ larva.

Histochemical reactions detecting oxidative enzymes were conducted in nematode eggs immediately after their separation from the uterus (0-day-old) and on days: $2,8,11,14,17,22,25,28,31,35$, and 41 of incubation. The procedure involved the following steps: eggs of a defined phase of embryonic development were placed in blocks cut out of a liver, frozen in dry ice, and sectioned in a cryostat at $-20^{\circ} \mathrm{C}$ for $10-\mu \mathrm{m}$ sections. Unfixed cryostat sections were subjected to reactions detecting NAD-dependent lactate dehydrogenase (LDH) (EC 1.1.1.27) and succinate dehydrogenase (SDH) (EC 1.3.99.1) according to $\mathrm{N} \mathrm{a} \mathrm{c} \mathrm{h} \mathrm{l} \mathrm{a} \mathrm{s} \mathrm{et} \mathrm{al.} \mathrm{(P} \mathrm{e} \mathrm{a} \mathrm{r} \mathrm{s} \mathrm{e} \mathrm{1972).} \mathrm{The} \mathrm{sections} \mathrm{were} \mathrm{incubated}$ for $30 \mathrm{~min}$ at $37^{\circ} \mathrm{C}$ and subsequently preserved in Baker solution. Specificity of this enzymatic reaction to substrate was determined based on histochemical reactions carried out in incubation media devoid of substrate.

\section{RESULTS}

Based on the microscopic observations of Ascaris sum eggs, incubated in $0.9 \% \mathrm{NaCl}$ solution (control), sequential steps of embryogenesis were determined and studied histochemically. Up to the second day of incubation the majority of eggs were at the stage of zygote. Between days 8 and 11 dominated sequential cleavage stages of blastomeres, although on day 11 the dominant stage was morula. On day 14 of incubation, the majority of eggs reached the stage of gastrula. $L_{1}$ stage was observed on day 17 and from day 22 on $-L_{2}$ stage.

In experimental culture No. 1 (with $P$. frequentans), the stage of zygote was observed in the eggs of Ascaris up to day 22 of incubation. Within 25-31 days of incubation the majority of eggs reached stages ranging from few blastomeres up to morula, while within $35-41$ days - the stage of gastrula dominated.

In experimental culture No. 2 (with $S$. chartarum), the stage of zygote was observed until day 14 of incubation. From day 17 on, the majority of eggs featured different cleavage stages up to morula. The stage of gastrula was observed on day 22 of incubation, while larva of stage $\mathrm{L}_{1}$ - on day 25 . From day $28 \mathrm{on}$, the majority of eggs contained $\mathrm{L}_{2}$ stage.

In experimental culture No. 3 (with $P$. frequentans and $S$. chartarum) the zygote stage persisted up to day 17 in the majority of eggs. Day 22 revealed 
sequential cleavage stages, and day 25 - the stage of gastrula. $\mathrm{L}_{1}$ stage dominated on day 28 , while $L_{2}$ larvae were observed on day 31 of culturc (Table 1).

T a b 1 e 1

Effect of Penicithun frequentans and Stachybotrys chartarum on embryonic development of Ascaris sewn

\begin{tabular}{|l|c|c|c|c|c|c|c|c|c|c|c|c|}
\hline $\begin{array}{c}\text { Day of } \\
\text { ineubation } \\
\text { Culture }\end{array}$ & 0 & 2 & 8 & 11 & 14 & 17 & 22 & 25 & 28 & 31 & 35 & 41 \\
\hline Control & $\mathrm{Z}$ & $\mathrm{Z}$ & $\mathrm{Bl}, \mathrm{M}$ & $\mathrm{M}$ & $\mathrm{G}$ & $\mathrm{L}_{1}$ & $\mathrm{~L}_{2}$ & $\mathrm{~L}_{2}$ & $\mathrm{~L}_{2}$ & $\mathrm{~L}_{2}$ & $\mathrm{~L}_{2}$ & $\mathrm{~L}_{2}$ \\
\hline No. 1 & $\mathrm{Z}$ & $\mathrm{Z}$ & $\mathrm{Z}$ & $\mathrm{Z}$ & $\mathrm{Z}$ & $\mathrm{Z}$ & $\mathrm{Z}$ & $\mathrm{Bl}_{1} \mathrm{M}$ & $\mathrm{Bl}_{1} \mathrm{M}$ & $\mathrm{Bl}, \mathrm{M}$ & $\mathrm{G}$ & $\mathrm{G}$ \\
\hline No. 2 & $\mathrm{Z}$ & $\mathrm{Z}$ & $\mathrm{Z}$ & $\mathrm{Z}$ & $\mathrm{Z}$ & $\mathrm{Bl}, \mathrm{M}$ & $\mathrm{G}$ & $\mathrm{L}_{1}$ & $\mathrm{~L}_{2}$ & $\mathrm{~L}_{2}$ & $\mathrm{~L}_{2}$ & $\mathrm{~L}_{2}$ \\
\hline No. 3 & $\mathrm{Z}$ & $\mathrm{Z}$ & $\mathrm{Z}$ & $\mathrm{Z}$ & $\mathrm{Z}$ & $\mathrm{Z}$ & $\mathbf{B l}, \mathrm{M}$ & $\mathrm{G}$ & $\mathrm{L}_{1}$ & $\mathrm{~L}_{2}$ & $\mathrm{~L}_{2}$ & $\mathrm{~L}_{2}$ \\
\hline
\end{tabular}

Explanations: $\mathbf{Z}$ - zygote; $\mathbf{B I}$ - blastomeres; $\mathbf{M}$ - morale; $\mathbf{G}$ - gastrula; $\mathbf{L}_{1}$ - larva $\mathbf{L}_{1} ; \mathbf{L}_{2}$ - larva $\mathbf{L}_{2}$

\section{Succinate dehydrogenase (SDH)}

Control culture. In 0-day-old eggs of Ascaris - isolated directly from the females uteri - the SDH activity was moderate or strong. The reaction product was visible in a form of numerous, minute formazan granules (Fig. 1). A similar magnitude of SDH reaction was observed in 2-day-old eggs containing zygote and in 8-day-old ones featuring early cleavage stages (Fig. 2). In the stage of morula (approximately day 11 of culture) an increase in the enzyme activity, ranging from a strong to a very strong, was observed. A very strong reaction to SDH in a form of very numerous formazan granules was recorded in Ascaris eggs at the stage of gastrula (day 14 of incubation) (Fig. 3). Slight weakening of the reaction to SDH occurred in eggs containing $\mathrm{L}_{1}$ larvae (day 17 of incubation) where a strong reaction was noted, and in eggs with $L_{2}$ (days 22 through 41 of culture) featuring a moderate reaction to SDH (Fig. 4).

Experimental culture No. 1 with Penicillium frequentans. On day 2 of Ascaris eggs incubation, moderate or strong reactions to SDH were observed in the cytoplasm of zygote, while on day 8 of culture a small decrease to a moderate level was recorded in reaction to SDH. A similarly moderate activity persisted in the cytoplasm of eggs up to day 22 (Fig. 5). On day 25 of culture some $50 \%$ of eggs showed initial phases of cleavage, mostly 2 and 4 blastomeres and occasionally the stage of morula. The cytoplasm of the blastomeres exhibited a moderate activity of SDH. Activity increase of SDH up to a moderate or strong level was observed on days 28 and 31 (Fig. 6), when most of eggs reached the stage of morula. In 35- and 41-day-old eggs at the stage of gastrula the reaction to SDH was moderate or strong. 

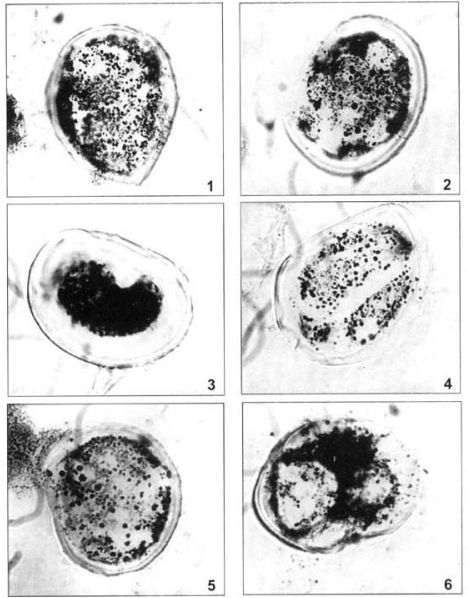

\section{Plate I}

Fig. 1. A moderate / strong activity of SDH in 0-day-old egg of A. sutom, dissected directly from uterus $(x$ 1000)

Fig. 2. A moderate / strong activity of SDH in 8-day-old egg of $A$. sutem (eleavage stage) in control culture $(\times 1000)$

Fig. 3. A very strong activity of SDH in 14-day-old egg of $A$. saum (gastrula) in control culture ( $\times$ 1000

Fig. 4. A moderste activity of SDH in 25-day-old egg of A. sam (stage of $\mathrm{L}_{1}$ larva) in control culture $(\times 1000)$

Fig. S. A moderate activity of SDH in 22-day-old cgg of A. sixum (zygote stage) in experimental culture No. 1 , with $P$. frequentans $(x 1000)$

Fig. 6. A moderate / strong activity of SDH in 28-day-old egg of A stum (cleavage stage) in experimental culture No. 1 , with $P$. frequentans ( $x$ 1000) 

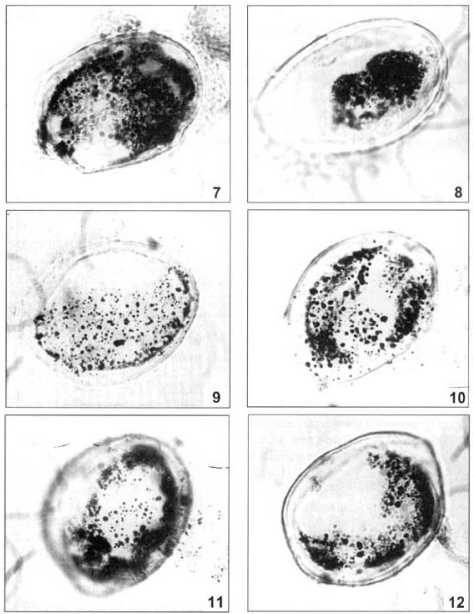

\section{Plate II}

Fig. 7. A moderate / strong activity of SDH in 11-day-old egg of A. sum (zygote stage) in experimental culture No. 2, with $S$. chartarum $(x$ 1000)

Fig. 8. A strong / very strong activity of SDH in 22-day-old egg of A. suum (gastrula stage) in experimental culture No. 2, with $S$. chartarum $(x$ 1000)

Fig. 9. A moderate activity of SDH in 25-day-old egg of A.sumn (stage of $\mathrm{L}_{1}$ larva) in experimental culture No. 2, with $S$ charianum $(x$ 1000)

Fig. 10. A moderate activity of $\mathrm{SDH}$ in 31-day-old egg of $A$. suan (stage of $\mathrm{L}_{2}$ larva) in experimental culture No. 2, with $S$. chartarum $(\times 1000)$

Fig. 11. A moderate activity of SDH in 8-day-old egg of A. sum (zygote stage) in experimental culture No. 3, with $P$. frequentans and $S$. charrarum ( $x$ 1000)

Fig. 12. A moderate activity of SDH in 25-day-old $\mathrm{egg}$ of $A$, suen (zygote stage) in experimental culture No. 3, with $P$. frequenians and $S$. chartarum ( $x$ 1000) 

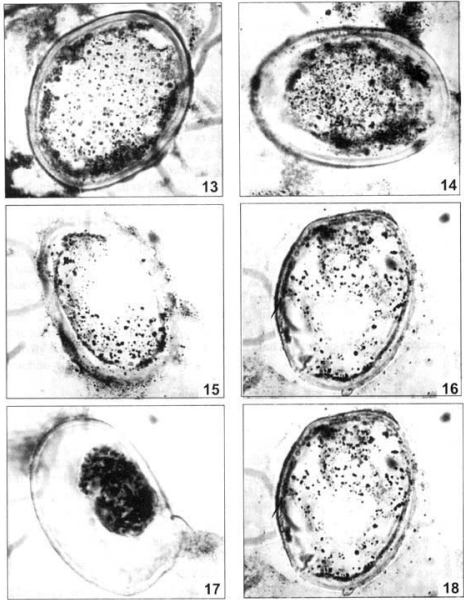

\section{Plate III}

Fig. 13. A moderate activity of LDH in 0-day-old egg of $A$. suem dissected directly from uterus ( $X$ $1000)$

Fig. 14. A moderate / strong activity of LDH in 8-day-old egg of $A$. sum (cleavage stage) in control culture $(x 1000)$

Fig. 15. A moderate activity of LDH in 22-day-old egg of A. stam (stage of L.2 larva) in control eulture $(x 1000)$

Fig. 16. A weak activity of LDH in 22-day-old egg of A. suum (2ygote stage) in experimental culture No. 1, with $P$. freqtientars $(\times 1000)$

Fig 17. A strong activity of LDH in 22-day-old egg of A. sum (gastrula stage) in experimental eulture No. 2, with $S$. cherrarum $(\times 1000)$

Fig 18. A moderate activity of LDH in 35-day-old egg of A. suum (stage of L2 larva) in experimental culture No. 3, with P. frequentans and $S$. chartarum ( $\times 1000)$ 
Experimental culture No. 2, with Stachybotrys chartar $u$ m. Eggs of Ascaris, remaining up to day 14 of incubation at the stage of zygote, exhibited a moderate or strong reaction to SDH (Fig. 7). In 17-day-old cleavage eggs ( $2-4$ blastomeres, up to morula) a strong reaction to $\mathrm{SDH}$ was recorded. At the stage of gastrula (22-day-old eggs) a strong or very strong reaction of the enzyme was observed in a form of numerous, coarse granules of the reaction product (Fig. 8). A distinct decline of the SDH-reaction to a moderate one was observed in sequential stages of the embryonic development - $\mathrm{L}_{1}$ larva (day 25 of incubation) (Fig. 9) and $\mathrm{L}_{2}$ larva (days 28 through 41 of culture) (Fig. 10).

Experimental culture No. 3 with P. frequentans and S. chartarum. The cytoplasm of Ascaris zygotes up to day 17 of culture showed moderate activity of SDH in a form of unevenly distributed formazan granules, most abundant below the egg shell (Fig. 11). At the stage of morula, reached by most of eggs on day 22 of incubations, a strong or very strong activity of SDH was observed. The remaining eggs, featuring anywhere from 2 to several blastomeres exhibited slightly weaker reaction - from a moderate to a strong onc. At the stage of gastrula (day 25) a strong SDH activity was recorded (Fig. 12), whereas $\mathrm{L}_{1}$ and $\mathrm{L}_{2}$ larvae showed a moderate reaction to SDH.

\section{Lactate dehydrogenase}

Control c u 1 ture. A weak activity of $\mathrm{LDH}$, in a form of few fine formazan granules was observed in the cytoplasm of 0 - and 2-day-old eggs of the nematode. The reaction product was visible mainly below the egg shell (Fig. 13). In carly cleavage stages (from day 8 on) the cytoplasm of the blastomeres exhibited weak or moderate activity of LDH (Fig. 14). At the stage of morula a moderate reaction to $\mathrm{LDH}$ was observed, while at the stage of gastrula - a strong one. Enzyme activity decrease was stated in subsequent phases of the embryonic development $-L_{1}$ and $L_{2}$ larvae, showing a moderate reaction to $\mathrm{LDH}$ (Fig. 15).

Experimental culture No. 1, with $P$. frequentans. The stage of zygote in eggs of Ascaris incubated with $P$. frequenians was observed up to day 22 . In this period a weak reaction to $\mathrm{LDH}$ - in a from of few fine granules of the reaction product unevenly distributed in the cytoplasm - was observed (Fig. 16). As late as on day 25 of incubation, most of eggs started their cleavage and the reaction to $\mathrm{LDH}$ in the blastomere cytoplasm was weak or moderate. Small increase in the of LDH reaction up to a moderate level was observed on days 28 and 31 of incubation, when the majority of eggs still remained at different stages of eleavage (from 2 blastomeres up to morula and blastula). Among 35- and 41-day-old eggs, in addition to the morula stage also gastrula stages were observed, featuring moderate or strong activity of $\mathrm{LDH}$. 
Ex p e r imen t a ] c u $1 \mathrm{t}$ u r c No. 2, with $S$. chartarum. Until day 14 , the eggs of Ascaris at the zygote stage, showed a weak reaction to LDH in a form of few fine granules. On day 17 the cytoplasm of blastomeres in eggs in the cleavage phase exhibited a moderate activity of LDH. At the stage of gastrula (22-day-egg) a strong activity of $\mathrm{LDH}$ was stated (Fig. 17). On day 25 of incubation, $\mathrm{L}_{1}$ larvac showed a decrease in the reaction ranging from a weak to moderate. At the stage of $\mathrm{L}_{2}$ larva, a moderate $\mathrm{LDH}$ activity was observed.

Experimental culture No. 3, with $P$. frequentans a nd $S$. chart ar um. Up to day 17 of incubation, a weak LDH activity was observed in the cytoplasm of Ascaris cggs. During the cleavage period, the LDH activity increased up to a moderate activity. At the stage of gastrula (day 25 of incubation) a moderate or strong reaction to LDH was stated, whereas in $\mathbf{L}_{1}$ larvae (28-day-old eggs) - a weak or moderate onc. $\mathbf{L}_{2}$ larvae exhibited moderate activity of LDH (Fig. 18).

A comparison of activity changes of dehydrogenases studied (SDH and LDH) in the course of embryogenesis of Ascaris suum in control and experimental (Nos. 1, 2 and 3) cultures were shown on Figs 19 and 20.

\section{DISCUSSION}

The obtained results of histoenzymatic study demonstrated that incubation of eggs of Ascaris sum with Penicillium frequentans and with Stachybotrys chartarum caused changes in the activity of oxidative enzymes during embryogenesis of this nematode. Our study (K u ź n a - G r y gi e l et al. 2001) revealed that the above-mentioned mould fungi caused, along with various morphological disorders, also retardation of the cleavage initiation and prolongation of sequential stages of the embryonic development of $A$. suum.

The study on the energy metabolism, carried out on an experimental model of Ascaris lumbricoides indicated that the developing eggs of this nematode represented aerobic metabolism consisting in lipid changes and transformations of triglycerides into carbohydrates ( $\mathrm{P}$ a s s e y and $\mathrm{F}$ a i r b a i r $\mathrm{n}$ 1957). Developing eggs of Ascaris contained a complete set of glycolytic enzymes and enzymes of tricarboxylic acids (B I o o m and E n t n c r 1965; B a r re t and B e is 1975; B e is and B a r r e t t 1975; B a r r e t 1976). The major respiratory substrate in early stages of embryogenesis are trehalose and glycogen. Later stages are dominated by lipid metabolism (B a r r e t t 1981) and re-synthesis of glycogen from lipids occurs in the course of glyoxylate cycle and $\beta$-oxidation (W a r d and F a i r b a i i n 1970, B a i r e t $t$ et al. 1970; L e e and A t k in s o n 1976).

During embryonic development of Ascaris in control culture a small increase in reactions to the oxidative enzymes studied was observed during cleavage as well as a distinct increase of their activity during gastrulation. These facts indicate intensified oxidative metabolism (i.e. oxygen demand and utilization) mainly in the gastrulation period and the early phase of organo- 


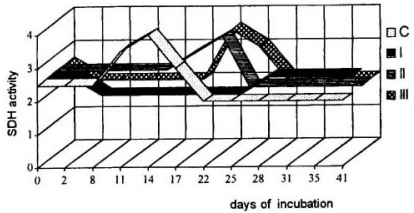

Fig. 19. SDH activity in the course of embryogenesis of $A$ scaris sum $(C$, control; L, incubation with $P$. frequentens, II, incubation with $S$. chartarum, III, incubation with $P$. frequentans and S. chararum]

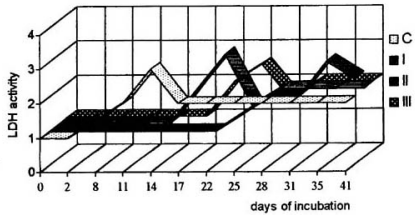

Fig. 20. LDH activity in the course of embryogenesis of Ascaris sum $(\mathrm{C}$, control; 1 , incubstion with $P$. frequentons; $\amalg$, incubation with $S$. chartarum, $\amalg$, incubation with $P$. frequentans and S. charianum)

genesis, which is undoubtedly associated, among other things, with morphogenetic movements and processes of cellular differentiation occurring at that time. A similar dynamics of changes of oxidative enzymes activity was recorded in embryogenesis of Toxocara canis - another parasitic nematode ( $\mathrm{K} \circ \mathrm{o} \mathrm{O}-$ dzic jcz y k 1998, 1999).

Incubation of $A$. suum eggs with $P$. frequentans caused a small activity decrease of SDH as early as in the zygote stage and in early phases of cleavage, whereas at the stages of morula, blastula, and gastrula in particular, effect of $P$. frequentans on activity of this enzyme was distinctly inhibiting. In the case of 
LDH, effect of this fungi species seems to be less significant-the activity of LDH in individual stages of embryonic development of Ascaris was similar as in control.

Stachybotrys chartarum similarly as $P$. frequentans delayed cleavage initiation, but in lesser extent it inhibited SHD activity. Only in the phase of gastrulation a small decrease in the activity of this enzyme was observed. Also LDH activity throughout the embryonic development showed small differences in relation to control, because only at the stage of $\mathrm{L}_{1}$ larva a small activity decrease of $\mathrm{LDH}$ was observed.

In the experimental treatment studying the combined effect of $P$. frequentans and $S$. chartarum on energy oxidative metabolism of the nematode eggs, a small decrease of SDH reactions was observed at the stage of zygote (similarly as in experimental culture No. 1) and throughout gastrulation. The observed, gradual increase of activity of this enzyme during cleavage, with a peak in the period of gastrulation, was lower, however, than in control. Also, a small decrcase of LDH activity observed in the $\mathrm{L}_{\mathrm{I}}$ stage (similarly as in culture No. 2 with $S$. chartarum) can indicate a certain synergistic action of those two fungi species on the oxidative metabolism of the nematode. The latter metabolism, in this experimental treatment, was expressed in lesser extent because of only half the amount of sccondary metabolites. As it has been demonstrated by numerous experiments, the dose of aflatoxin plays a decisive role in its toxicity (S e ń c z u k 1999)

Comparing the activity of the studied oxidoreductive enzymes - lactate dehydrogenase (LDH) and succinate dehydrogenase (SDH) - markers of glycolysis and the Krebs cycle (Figs 19 and 20), it is evident that in the course of $A$. suum embryogenesis, the metabolites of the studied species of mould fungi cause, in particular, a decrease in SDH activity. In addition, the present results give a sound evidence on the inhibiting action of mycelia of Penicillium frequentans on the SDH activity in the course of A. suum embryogenesis.

The earlier-mentioned antagonistic effects on eggs of Ascaris were most probably causcd by the sccondary metabolites of $P$. frequentans and $S$. chartarum described as mycotoxins (aflatoxins, frequentin, stachybotrytoxin) (P i o a t e k 1999). It has been known that aflatoxin in vitro inhibits synthesis of DNA and RNA in nuclei of hepatocytes, which in turn leads to disorders in the synthesis of cnzymatic proteins (A l e k s a n d r ow i c z 1970). These facts can explain the retardation of the cleavage and on the other hand the inhibition of SDH activity throughout embryonic development of the large pig roundworm.

\section{REFERENCES}

A loksandrowicz J. 1970. Mikotoksyny i ich tola $w$ ontogenezie ze szczegblnym uwzglèdnieniem chorób krwi. Pol. Tyg Lek. 25: 1100-1103.

B a I r e t 1 J. 1976. Intermediary metabolism in Asearis eggs. Ia: Biochemistry of parasites and host-parasite relationships. Van den Bossche H. Elsevier, North Holland Biochemical Press, Amsterdam: $117-123$. 
B a r r e t t J., B c is I. 1975. Energy metabolism in developing Ascaris lunbricoides eggs, 1. The gycolytic enzymes. Develop. Biol. 42: 181-187.

Barrett J. W, Ward C. W, Fa i r ba i n D. 1970. The glyoxyliste cycle and the conversion of triglycerides to carbohydrates in develpoing eggs of Ascaris hombricoides. Comp. Biochem. Physiol. 35: 577-586.

B e i s I, B a r re t t J. 1975. Energy metabolism in developing Ascaris hmbricoides eggs. II. The steady state content of intermodiary metabolites. Develop. Biol 42; $188-195$.

B $100 \mathrm{~m} \mathrm{~S}$., Entan $\mathrm{N}$. 1965. Mitochondrial enzymes in developing larvae of Ascaris lumbricoides, Biochim. Biophys. Acta 99: 22-31.

C o ch r a ne V.W. 1958. Physiology of fungi. John Wiley \& Sons, New York.

D h in g r a O.D., K h a re M.N. 1973. Biological coatrol of Rhizoctonia bataticola on urid bean. Phytopath. Z. $76: 23-29$.

D om s c b K. H. 1960. Des Pilzspektrum einer Bodenprobe. 3. Nechweis der Einzelpilze. Arch. Mikrobiol. 35: 310-339.

D o $\mathrm{n} \mathrm{c}$ h K. H. 1963. Der Einfluss saprophytischer Bodenpilze auf die Jugendentwicklung höherer Pीanzen. Z. Pnkrankh. Pflschutz. 70: 470-475.

$\mathrm{D}$ om $5 \mathrm{c} \mathrm{h} \mathrm{K.} \mathrm{H.,} \mathrm{G} \mathrm{a} \mathrm{m} \mathrm{s} \mathrm{W.} \mathrm{1968.} \mathrm{Die} \mathrm{Bedeutung} \mathrm{vorfruchtabhdngiger} \mathrm{Verschiebungen} \mathrm{in} \mathrm{der}$ Bodeamikrofora, 2. Antagonistische Einhsse auf Pathogene Bodenpike. Phytopath Z. 63: $165-176$.

$\mathrm{G}$ h a $\mathrm{ff}$ a $\mathrm{r}$ A, F a t i m a K. 1970: Inhibition of Trichoderma viride by Stachybotrys atra. Sci. Indust. 7: $88-90$.

K a n e r s k y a I.G. 1966. Decompesition of methylcellulose by soil fungi. Mikrobiologiya 35: $868-870$.

$\mathrm{K}$ a I* i $^{\circ}$ h I.K. 1972 Interaction between microflora of caterpillars of the Siberian silkworm and entomogenous fungi. Mikol. Fitopat. 6: 157-159.

$\mathrm{K}$ h a r c he a KO S.M. 1960 . The antibiotic properties in the Monoverticillata section of the genus Penicillium isolated from the rhizosphere of agricultural plants in the Ukraine. 2 . The antibiotic properties in relation to bacteria and fungi Mikrobiol. $\mathrm{Zh}$. 22: 45-51.

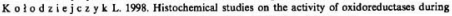
the embryonic development of Toxocara canis. Zool. Pol. 43: 55-67.

Kołodziejczyk L 1999. Histochemical study on the acrobic energy metabolism of developing eggs of Toxccara canis (Nematoda). Zool. Pol. 44: 37-45.

K u nert J. 1992. On the mechanism of penetration of ovicidal fungi through eggs-shell of parasitic nematodes. Decomposition of chitinous and ascarosidose layers. Folia Perasitol. 39: $61-66$.

Kuía-Grygiel W, Kolodziejczyk L, IanowiczK, Mazurkiew i z $-\mathbf{Z}$ a pa lo wi c z K. 2001. Effect of some saprotrophic fungi on the embryonic development of Ascaris sum (Nemaioda). Acta Mycol. (In press).

L i u Sh., V a u g h a n E.K. 1965. Control of Pythium infection in table beet seedlings by antagonistic microorganisms. Phytopathology, 55: 64-68.

L e e A. L, Atkinson H. J. 1976. Metsbolism In: Physiology of nematodes. Macmillan Press London.

L y 5 e $<$ H. 1963. Effect of certain soil organismus on the eggs of parasitic roundworm. Nature 31: 925.

L y s e k H. 1967. Biological liquidation of ascarid eggs in spriag pasture soil. Acta Parasitol. Pol 15: $253-267$.

L y s e k H. 1979. To the problem of possible biological control of geobelminthosis. Helminthologia 16: $107-113$.

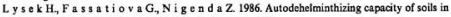
two Mexican Iccalities. Helminthologia 23: 237-241.

Mazurkiewicz-Zapatowicz K. Janowicz K, Kuzna-Grygiel W. 1999. Influence of excrections of ebosen Penicilliam species on the population of Gibhadera rostochiensis. Acta Mycol 34: 289-297. 
M i r c hi u k T. G., B e 1 a y a T. I 1965. Mycoflora of Gwinea tropical soils and is biological properties. Mikrobjologiya 34: 1049-1055.

$\mathrm{M} \mathrm{iz} \mathrm{ga} \mathrm{j} \mathrm{k} \mathrm{a} \mathrm{H.} \mathrm{1993.} \mathrm{The} \mathrm{distribution} \mathrm{and} \mathrm{survival} \mathrm{of} \mathrm{eggs} \mathrm{of} \mathrm{Ascarts} \mathrm{stam} \mathrm{in} \mathrm{six} \mathrm{different}$ natural soil profiles. Acta Parasitol. 38: 170-174.

M i z g a j 5 is a H. 1994. Wplyw crynników biotycznych aa jaja Ascarís spp. Wiad. Parazytol. 40: $299-303$.

O r a z O $\mathrm{KH} . \mathrm{N}, \mathrm{Siz}$ ov a T.P.1966. Antagonistic properties of Penicilitum species isolated from the soils in the Turkmenian SSR. Bull. Moskov. Obshch. Ispyt. Prir., OTD. Biol. 71: $118-130$.

O y a H., C o st e 11 o L. C, $\mathrm{S}$ m it h W. N. 1963. The comparative biochemistry of developiag Ascaris eggs. II. Changes in cytochrome coxidase activity during embryonation. I. Cell Comp. Physicl. 62: 287-293.

$\mathrm{P}$ as s e y R. F, F a i r ba i in D. 1957. The conversion of fat to carbohydrate during embryonation of Ascaris eggs. Can. J. Biochem. Physiol. 35: 511-525.

Pcarsc A. G. E. 1972. Histocbemistry. 2. Theoretical and applied. Churchill Livingstonc. Edinburgh, London.

P i o n te k M. 1999. Grzyby pleśniowe. Wydawnictwo Politechniki Zielonogórskiej. Zielona Góra.

R a i J.N., S a $x$ e n a V.C. 1975. Sclerotial mycoflora and its role in natural biological control of white - rot disease. PI. Soil 43: $509-513$.

S c ri c zu k W. (ed.) 1999. Toksykologia. PZWL Warszawa.

$\mathrm{S}$ iz o v a T.P, V a s i n V.B. 1962 The mieroflors of the oak thizosphere. Ball. Moskov. Obshch. Ispyt. Pris, OTD, Biol. 66: 102-115.

T r i b e H.T.1960. Decomposition of buried cellulose film, with special reference to the ecology of certain soil fungi. In: D. P a r k i n s o n, S. J. W a i d (eds.), Eeology of soil fungi. Liverpool Univ. Press: $246-256$.

Ward C. W, F a ir b a i r D D. 1970. Enzymes of $\beta$-oxidation and their function during development of Ascaris tumbricoides eggs. Develop. Biot. 22: 366-387.

\section{Wplyw Penicillium frequentans i Stachybotrys chartarum na metabolizm oddechowy rozwijających sie jaj Ascaris suum}

\section{Streszezenie}

Przy użycia metod histoenzymatyczaych okreílono wplyw saprotroficznyeh grzybów glebowych Penieilium frequentans i Siachybotrys chertanum na metabolizm oddechowy w czasie embriogenezy pasożytniczego nicienia Ascaris suwn.

Na podstawic histochemicznej oceny aktywnosci enzymów glikolizy (dehydrogenaza mleczanowa) (LDH) oraz cyklu kwasow trojksrboksylowych (dehydrogenaza bursztynianowa) (SDH) stwierdzono zmiany w tlenowym metabolizmie energetycznym rozwijajacych sie jaj A. suum.

$\mathrm{Z}$ testowanych gatunków grzybów - glównic wpływ $P$. frequentans powodowal zaburzenia w procesach oddychania komórkowego, które manifestowaly się spadkiem aktywności SDH w okresie gastrulacji. Inkubacja jaj Ascaris wraz z grzybnią $S$, charicum oraz razem z $P$. frequentans wplywała $w$ niewielkim stopniu na upośledzenie metabolizmu oddechowego nicienia. 